\title{
Ketahanan Genotipe Kedelai terhadap Hama Pengisap Polong, Riptortus linearis F. (Hemiptera: Alydidae)
}

\section{The Resistance of Soybean Genotypes to Stink Bug, Riptortus linearis F. (Hemiptera: Alydidae)}

\author{
Ayda Krisnawati ${ }^{*}$, Marida Santi Yudha Ika Bayu ${ }^{1}$, dan Mochammad Muchlish Adie ${ }^{1}$ \\ ${ }^{1}$ Balai Penelitian Tanaman Aneka Kacang dan Umbi \\ Jl. Raya Kendalpayak Km 8 Malang 65101, Jawa Timur, Indonesia
}

Diterima 12 Maret 2019/Disetujui 30 Juli 2019

\begin{abstract}
The brown stink bug, Riptortus linearis, is the most dominant of soybean pod sucking pest in Indonesia. The objectives of the study were to identify the resistance of soybean genotypes against brown stink bug and to determine the relationship of agronomic characters with the intensity of pod and seed damages. The research was conducted at Balitkabi (Malang, Indonesia) from April to August 2018. Thirteen genotypes were assessed for their resistance to brown stink bug under choice and no-choice tests. A randomized block design was carried out with three replicates. The number of punctures on seed, seed and pod damages intensity on the no-choice test was higher than those under the choice test. Under the choice test, the pod damage ranged from 19.40-41.68\% (average of 29.51\%), and the seed damage ranged from 19.31-39.90\% (average of $26.80 \%$ ). Under the no-choice test, the pod damage ranged from 25.77-43.58\% (average of 37.41\%), and the seed damage ranged from 21.30-58.29\% (average of 34.27\%). The $11 \mathrm{AB}$ and 19BE showed consistently resistant based on pod and seed damage under the choice test. Under the no-choice-test, 19BE showed consistently resistant. The path analysis showed that an increase in the number of seeds would possibly increase the number of punctures on the seed and then contribute to the increase of yield losses. The 19BE which showed consistently resistant to brown stink bug was recommended to be further tested in the adaptation trial and released as superior variety.
\end{abstract}

Keywords: agronomic character, choice test, damage intensity, no-choice test

\section{ABSTRAK}

Serangga kepik coklat, $\underline{\text { Riptortus }}$ linearis, merupakan hama pengisap polong dominan pada pertanaman kedelai di Indonesia. Tujuan penelitian adalah menilai ketahanan beberapa genotipe kedelai terhadap hama kepik coklat dan menentukan pola keterkaitan karakter agronomi dengan intensitas kerusakan polong dan biji. Penelitian dilakukan di Balitkabi (Malang, Indonesia) dari bulan April hingga Agustus 2018. Sebanyak 13 genotipe kedelai dievaluasi ketahanannya terhadap hama kepik coklat menggunakan rancangan acak kelompok dan diulang tiga kali. Uji ketahanan menggunakan metode dengan pilihan (choice test) dan tanpa pilihan (no-choice test). Jumlah tusukan pada biji, intensitas kerusakan polong maupun biji pada uji tanpa pilihan lebih tinggi dibandingkan pada uji dengan pilihan. Pada uji dengan pilihan rentang rentang kerusakan polong antara 19.40-41.68\% (rata-rata 29.51\%) dan kisaran kerusakan biji antara 19.31-39.90\% (rata-rata 26.80\%). Pada uji tanpa pilihan rentang kerusakan polong antara 25.77-43.58\% (rata-rata 37.41\%), intensitas kerusakan biji antara 21.30 58.29\% (rata-rata 34.27\%). Genotipe 11 AB dan 19 BE konsisten tahan berdasarkan intensitas kerusakan polong maupun biji pada uji dengan pilihan, namun pada uji tanpa pilihan hanya genotipe 19 BE yang konsisten tahan terhadap hama kepik coklat. Hasil sidik lintas memperlihatkan bahwa semakin banyakjumlah biji/tanaman akan meningkatan kemungkinan jumlah tusukan pada biji dan berpeluang akan meningkatkan kerugian hasil biji. Genotipe 19 BE yang konsisten tahan terhadap hama kepik coklat berpeluang diuji lanjut pada uji adaptasi dan dilepas sebagai varietas unggul.

Kata kunci: intensitas kerusakan, karakter agronomi, uji pilihan, uji tanpa pilihan

\footnotetext{
*Penulis untuk korespondensi. e-mail:my_ayda@yahoo.com
} 


\section{PENDAHULUAN}

Serangga pengisap polong kepik coklat, Riptortus linearis, merupakan hama perusak polong terpenting di Indonesia. Sebaran hama ini berada pada lintas lokasi dan lintas musim tanam kedelai, dan dilaporkan menyebabkan kehilangan hasil kedelai hingga 79\% (Arifin dan Tengkano, 2008). Hama pengisap polong tidak hanya menjadi masalah budidaya kedelai di daerah tropis Indonesia, namun dilaporkan juga terjadi di beberapa sentra produksi kedelai seperti di Brasil, Jepang, dan Korea Selatan (Kim dan Lim, 2010; Mainali dan Lim, 2012). Di Amerika dan Brasilia dilaporkan hama pengisap polong penting adalah hama kepik hijau Nezara viridula (Tillman, 2013).

Cara merusak serangga hama pengisap polong adalah dengan cara menusukkan stiletnya pada permukaan polong dan biji kedelai, sehingga menyebabkan biji kedelai menjadi kempes (Bayu dan Tengkano, 2014; Rahman dan Lim, 2017). Dengan demikian kerugiannya bersifat kuantitas (penurunan hasil) dan kualitas (penurunan vigor benih). Besarnya kerugian hasil minimum ditentukan oleh tingkat ketahanan varietas dan saat terjadinya serangan (Depieri dan Panizzi, 2011). Mussers et al. (2011) mengemukakan fase paling kritis tanaman kedelai terhadap serangan hama pengisap polong berada pada R5-R6. Peneliti lainnya mengemukakan bahwa serangga kelompok Hemiptera lebih menyukai polong muda hingga fase perkembangan biji yakni pada fase R3-R5 (Bae et al., 2014). Walaupun demikian Owens et al. (2013) mengatakan bahwa fase pengisian polong dan biji memiliki tingkat kepekaan yang sama terhadap hama pengisap polong.

Selama ini, pencegahan dan pengurangan kerugian hasil akibat serangan hama maupun penyakit dilakukan dengan penggunaan insektisida kimia maupun nabati (Siburian et al., 2013; Nurkartika et al., 2017). Tersedianya varietas kedelai yang relatif toleran terhadap hama pengisap polong, tidak hanya penting dalam hal penyelamatan hasil namun juga aman bagi lingkungan. Peluang peningkatan ketahanan kedelai terhadap hama pengisap polong cukup besar. Asadi et al. (2012) yang menelaah kendali genetik ketahanan kedelai terhadap kepik coklat mengemukakan bahwa ketahanan dari genotipe kedelai B4400 dan B3802 terhadap hama kepik coklat dikendalikan oleh dua gen resesif yang berlokasi pada lokus yang berbeda. Artinya karakter ketahanannya bersifat terwariskan. Genotipe kedelai asal Brasil yaitu IAC 100 dinilai tahan terhadap hama kepik coklat (Suharsono dan Sulistyowati, 2012; Da Graca et al., 2016).

Program perakitan varietas kedelai tahan terhadap hama kepik coklat juga memerlukan pemahaman tentang faktor penentu ketahanan dan seleksi ketahanan. Seleksi dapat dilakukan secara langsung (misalnya penurunan hasil) atau dengan menggunakan seleksi tak langsung. De Godoi dan Pinheiro (2009) menyarankan seleksi ketahanan terhadap kompleks hama pengisap polong menggunakan karakter kerusakan polong, khususnya pada kedelai generasi F2 hingga F4, sedangkan pada populasi lanjut disarankan seleksi dengan menggunakan karakter tusukan pada biji. Skrining ketahanan terhadap 10 genotipe kedelai yang dilakukan oleh Krisnawati et al. (2016) dengan menggunakan intensitas kerusakan biji berhasil mengelompokkannya menjadi peka, moderat dan tahan terhadap hama kepik coklat. Bayu et al. (2017) menilai ketahanan 16 genotipe di lapang berdasarkan intensitas kerusakan polong dan biji, dan berhasil memperoleh tiga genotipe kedelai tergolong agak tahan terhadap kompleks hama pengisap polong.

Penelitian perakitan varietas unggul kedelai berdaya hasil tinggi yang telah dilakukan telah menghasilkan 10 genotipe terbaik diantara genotipe yang diuji lainnya dari aspek hasil biji dan ukuran biji. Selain itu, aspek ketahanan terhadap hama kepik coklat merupakan hal yang penting untuk mencegah kerugian yang bersifat kuantitas (penurunan hasil) dan kualitas (benih), sehingga kesepuluh genotipe tersebut perlu diuji ketahanannya. Penelitian dilakukan untuk menilai ketahanan dari beberapa genotipe kedelai terhadap hama kepik coklat dan menentukan pola keterkaitan karakter agronomi dengan intensitas kerusakan polong dan biji.

\section{BAHAN DAN METODE}

Penelitian dilakukan di Balai Penelitian Tanaman Aneka Kacang dan Umbi (Balitkabi), di Malang, Jawa Timur, Indonesia. Penelitian dilaksanakan pada musim kemarau yakni dari bulan April hingga Agustus 2018.

Penelitian dilaksanakan dengan menggunakan rancangan acak kelompok dengan 13 genotipe sebagai perlakuan dimana setiap genotipe diulang sebanyak tiga kali. Evaluasi ketahanan terhadap hama kepik coklat dilakukan terhadap 10 genotipe kedelai generasi F8 (11 AB, 13 ED, 14 DD, 19 BE, 25 EC, G511H/Kaba//Kaba///Kaba-8-6, G511H/ Anjs//Anjs-2-10, G511H/Anjs-1-3, G511H/Anj//Anj///Anj11-2, G511H/Arg// Arg-2-1) dan tiga varietas pembanding, yaitu Demas 1 (hasil tinggi, ukuran biji sedang), Anjasmoro (hasil tinggi, biji besar), dan G100H (tahan hama kepik coklat). Kesepuluh genotipe merupakan hasil persilangan yang telah melalui proses seleksi hingga generasi F8 yang memiliki keunggulan berdasar hasil biji dan ukuran biji. Karakteristik genotipe kedelai bahan penelitian disajikan pada Tabel 1.

Penanaman dilakukan di pot plastik berdiameter $18 \mathrm{~cm}$ yang berisi campuran media tanah dan pupuk kandang. Penanaman dilakukan sesuai dengan umur berbunga masing-masing genotipe agar terjadi pembungaan bersamaan. Pemeliharan tanaman dilakukan secara optimal. Pengendalian hama dilakukan dengan menggunakan insektisida berbahan aktif sipermetrin pada 8 hari setelah tanam (HST), dilanjutkan dengan aplikasi insektisida berbahan aktif sihalotrin pada 14, 21, dan 28 HST untuk mengendalikan hama daun. Setelah tanaman berumur 28 HST tidak dilakukan aplikasi insektisida.

Penelitian dilakukan dengan menggunakan metode dengan pilihan (choice-test) dan tanpa pilihan (no choicetest). Penelitian dengan uji tanpa pilihan dilakukan dengan cara menempatkan masing-masing genotipe yang diuji dalam kurungan kasa berwarna putih dengan rangka besi (diameter $30 \mathrm{~cm}$ dan tinggi $60 \mathrm{~cm}$ ) pada saat tanaman berumur 35 HST. Uji dengan pilihan dilakukan dengan cara 
Krisnawati et al. / J. Agron. Indonesia 47(2):141-148

Tabel 1. Karakteristik genotipe kedelai bahan penelitian uji ketahanan hama pengisap polong

\begin{tabular}{lllllll}
\hline \multirow{2}{*}{ No } & \multirow{2}{*}{ Genotipe } & \multirow{2}{*}{ Kode } & Silsilah & \multicolumn{3}{c}{ Warna } \\
\cline { 5 - 6 } & & & Kulit polong & Kulit biji & Trikoma polong \\
\hline 1 & $11 \mathrm{AB}$ & $\mathrm{G} 1$ & Hasil persilangan & $\mathrm{Cm}$ & $\mathrm{Kn}$ & $\mathrm{Cm}$ \\
2 & $13 \mathrm{ED}$ & $\mathrm{G} 2$ & Hasil persilangan & $\mathrm{Ct}$ & $\mathrm{Kn}$ & $\mathrm{Ck}$ \\
3 & $14 \mathrm{DD}$ & $\mathrm{G} 3$ & Hasil persilangan & $\mathrm{Cm}$ & $\mathrm{Kn}$ & $\mathrm{Ck}$ \\
4 & $19 \mathrm{BE}$ & $\mathrm{G} 4$ & Hasil persilangan & $\mathrm{Cm}$ & $\mathrm{Kn}$ & $\mathrm{Ck}$ \\
5 & $25 \mathrm{EC}$ & $\mathrm{G} 5$ & Hasil persilangan & $\mathrm{Cm}$ & $\mathrm{Kn}$ & $\mathrm{Ck}$ \\
6 & G511H/Kaba//Kaba///Kaba-8-6 & $\mathrm{G} 6$ & Hasil persilangan & $\mathrm{Ck}$ & $\mathrm{Kn}$ & $\mathrm{Ck}$ \\
7 & G511H/Anj//Anj-2-10 & $\mathrm{G} 7$ & Hasil persilangan & $\mathrm{Ct}$ & $\mathrm{Kn}$ & $\mathrm{Pt}$ \\
8 & G511H/Anj-1-3 & $\mathrm{G} 8$ & Hasil persilangan & $\mathrm{Kn}$ & $\mathrm{Kn}$ & $\mathrm{Ck}$ \\
9 & G511H/Anj//Anj///Anj-11-2 & $\mathrm{G} 9$ & Hasil persilangan & $\mathrm{Ck}$ & $\mathrm{Kn}$ & $\mathrm{Pt}$ \\
10 & G511H/Arg//Arg-2-1 & $\mathrm{G} 10$ & Hasil persilangan & $\mathrm{Cm}$ & $\mathrm{Kn}$ & $\mathrm{Pt}$ \\
11 & Demas 1 & $\mathrm{G} 11$ & Varietas unggul & $\mathrm{Ck}$ & $\mathrm{Kn}$ & $\mathrm{Ck}$ \\
12 & Anjasmoro & $\mathrm{G} 12$ & Varietas unggul & $\mathrm{Kn}$ & $\mathrm{Kn}$ & $\mathrm{Pt}$ \\
13 & G100H & $\mathrm{G} 13$ & Hasil persilangan & $\mathrm{Ck}$ & $\mathrm{Kn}$ & $\mathrm{Pt}$ \\
\hline
\end{tabular}

Keterangan: $\mathrm{Cm}=$ coklat muda; $\mathrm{Ck}=$ coklat $\mathrm{Ct}=$ coklat tua; $\mathrm{Pt}=$ putih; $\mathrm{Kn}=$ kuning

menempatkan 13 genotipe yang diuji dalam satu kurungan kasa pada saat tanaman berumur 35 HST. Infestasi $R$. linearis dilakukan pada saat tanaman memasuki fase R5 sebanyak satu pasang imago (berumur 5 hari setelah lahir) per rumpun tanaman pada pukul 14.00 WIB, sehingga jumlah imago yang diinfestasikan sebanyak 13 pasang/ulangan (=1 pasang/genotipe/ulangan). Panen dilakukan setelah polong telah matang. Seluruh polong dari setiap tanaman dikumpulkan dan diamati intensitas kerusakan polong dan intensitas kerusakan biji. Pengamatan intensitas kerusakan polong dan biji dilakukan dengan cara menghitung jumlah polong dan biji terserang. Polong dan biji terserang ditandai dengan adanya bekas tusukan pada polong dan biji kedelai. Pengamatan juga dilakukan terhadap jumlah tusukan pada polong dan biji dengan cara menghitung jumlah tusukan di bawah mikroskop binokuler. Intensitas serangan polong dan biji dihitung dengan rumus:

Intensitas kerusakan polong $=\frac{\text { jumlah polong terserang }}{\text { jumlah polong yang diamati }} \times 100 \%$ Intensitas kerusakan biji $=\frac{j \text { umlah biji terserang }}{\text { jumlah biji yang diamati }} \times 100 \%$

Pengelompokan ketahanan terhadap hama kepik coklat berdasarkan intensitas kerusakan (polong atau biji) mengikuti Asadi et al. (2012) sebagai berikut : tahan (0$20 \%$ ), agak tahan (21-40\%), agak rentan (41-60\%), rentan $(61-80 \%)$ dan sangat rentan $(>80 \%)$.

Pengamatan karakter agronomi yang dilakukan setelah panen meliputi tinggi tanaman (diukur dari pangkal batang hingga titik tumbuh dalam satuan $\mathrm{cm}$ ), jumlah polong per tanaman (jumlah polong bernas), jumlah biji per tanaman, dan bobot biji per tanaman $(\mathrm{g})$.

Analisis data dilakukan terhadap setiap karakter yang diamati, yaitu analisis deskriptif (rata-rata, nilai minimum dan nilai maksimum), korelasi, dan sidik lintas (Singh dan Chaudhary, 1977).

\section{HASIL DAN PEMBAHASAN}

\section{Penilaian Ketahanan}

Kerusakan polong maupun biji pada uji tanpa pilihan memperlihatkan intensitas yang lebih tinggi dibandingkan dengan uji dengan pilihan (Tabel 2, Gambar 1). Krisnawati et al. (2017) juga mendapatkan rata-rata intensitas kerusakan biji pada uji tanpa pilihan (34.24\%) lebih tinggi dibandingkan dengan uji dengan pilihan (31.73\%). Pada uji tanpa pilihan, serangga hama dipaksa untuk berinteraksi dengan inang sehingga tingkat kerusakan akan lebih besar.

Jumlah tusukan beragam antar genotipe kedelai yang diuji (Gambar 1). Pada uji dengan pilihan, genotipe pembanding tahan $\mathrm{G} 100 \mathrm{H}$ (G13) memiliki tusukan terendah yakni 7 tusukan dan yang tertinggi terdapat pada genotipe G511H/Anjs-1-3 (G8), yaitu sebanyak 17 tusukan. Pada uji tanpa pilihan, genotipe pembanding tahan $\mathrm{G} 100 \mathrm{H}$ konsisten memiliki tusukan terendah yaitu 6.50 tusukan pada biji dan yang tertinggi terdapat pada genotipe G511H/Anj//Anj/// Anj-11-2 (G9) sebanyak 24.83 tusukan.

Pengelompokan ketahanan dari 13 genotipe dengan uji dengan pilihan berdasarkan intensitas kerusakan polong diperoleh empat genotipe tergolong tahan, delapan genotipe tergolong agak tahan, dan satu genotipe berkriteria agak rentan terhadap hama kepik coklat. Jika pengelompokan ketahanan berdasarkan intensitas kerusakan biji, maka dari 13 genotipe kedelai terkelompok menjadi tahan sebanyak tujuh genotipe, agak tahan sebanyak lima genotipe, dan satu genotipe tergolong agak rentan (Tabel 3, Gambar 2). Terlihat intensitas kerusakan polong $(24.68 \%)$ lebih tinggi 
Tabel 2. Data deskriptif karakter agronomi dan intensitas serangan hama pengisap polong

\begin{tabular}{lcccccc}
\hline \multirow{2}{*}{ Karakter } & \multicolumn{3}{c}{ Dengan pilihan } & \multicolumn{3}{c}{ Tanpa pilihan } \\
\cline { 2 - 7 } & Rata-rata \pm SD & $\begin{array}{c}\text { Nilai } \\
\text { minimum }\end{array}$ & $\begin{array}{c}\text { Nilai } \\
\text { maksimum }\end{array}$ & Rata-rata \pm SD & $\begin{array}{c}\text { Nilai } \\
\text { minimum }\end{array}$ & $\begin{array}{c}\text { Nilai } \\
\text { maksimum }\end{array}$ \\
\hline TTG & $56.52 \pm 11.73$ & 35.83 & 70.83 & $58.48 \pm 12.52$ & 39.67 & 76.33 \\
JPL & $19.46 \pm 1.40$ & 16.00 & 21.33 & $20.38 \pm 3.80$ & 15.83 & 29.83 \\
JBJ & $39.15 \pm 3.64$ & 33.50 & 46.00 & $46.87 \pm 10.43$ & 30.33 & 66.83 \\
B/T & $3.97 \pm 0.53$ & 2.90 & 4.67 & $4.08 \pm 0.75$ & 2.77 & 5.40 \\
TSBJ & $10.93 \pm 3.22$ & 7.00 & 17.00 & $13.48 \pm 5.57$ & 6.50 & 24.83 \\
ITPL & $29.51 \pm 5.46$ & 19.40 & 41.68 & $37.41 \pm 5.38$ & 25.77 & 43.58 \\
ITBJ & $26.80 \pm 6.18$ & 19.31 & 39.90 & $34.37 \pm 10.65$ & 21.30 & 58.29 \\
\hline Ket & & & & & &
\end{tabular}

Keterangan: TTG = tinggi tanaman $(\mathrm{cm}) ; \mathrm{JPL}=$ jumlah polong per tanaman; JBJ = jumlah biji per tanaman; B/T = bobot biji per tanaman (g); TSBJ = jumlah tusukan pada biji; ITPL = intensitas kerusakan polong (\%); ITBJ = intensitas kerusakan biji (\%); SD = standar deviasi

dibandingkan dengan intensitas kerusakan biji (20.93\%). Genotipe pembanding tahan G100H (G13) menunjukkan kriteria agak tahan berdasar intensitas kerusakan polong namun menjadi tahan berdasarkan intensitas kerusakan biji. Terdapat dua genotipe kedelai yang konsisten tahan baik berdasarkan intensitas kerusakan polong maupun biji yaitu 11 AB (G1) dan 19 BE (G4). Penilaian ketahanan beberapa genotipe kedelai terhadap hama kepik coklat oleh Bayu et al. (2017) mendapatkan tiga genotipe kedelai yang agak tahan berdasarkan intensitas kerusakan polong maupun berdasarkan intensitas kerusakan biji, sedangkan Krisnawati dan Adie (2018) mendapatkan satu genotipe kedelai (G511H/Anj//Anj-2-8) yang berkategori tahan.

Pemetaan ketahanan genotipe kedelai berdasarkan uji tanpa pilihan (Tabel 3, Gambar 2), berdasarkan intensitas kerusakan polong terpetakan sebanyak satu genotipe berkriteria tahan, enam genotipe agak tahan, dan enam genotipe tergolong agak rentan. Berdasarkan intensitas kerusakan biji terdapat tiga genotipe tergolong tahan, enam genotipe agak tahan, tiga genotipe agak rentan, dan satu genotipe tergolong rentan (Tabel 4). Genotipe 19 BE (G4) konsisten tahan menurut uji dengan maupun tanpa pilihan. Genotipe pembanding tahan $\mathrm{G} 100 \mathrm{H}$ (G13) juga konsisten berkriteria agak tahan pada kedua uji berdasarkan intensitas kerusakan polong dan menjadi tahan jika berdasarkan intensitas kerusakan biji. Uji tanpa pilihan memberikan tekanan yang lebih berat terhadap uji ketahanan terhadap hama kepik coklat dibandingkan uji dengan pilihan, artinya genotipe kedelai yang terseleksi tahan pada uji tanpa pilihan akan berpeluang tahan pada uji dengan pilihan.

\section{Karakter Agronomi}

Keragaan tinggi tanaman dari 13 genotipe kedelai yang diuji dengan pilihan berada dalam kondisi normal. Genotipe 14 DD (G3) memiliki keragaan tanaman yang tertinggi.

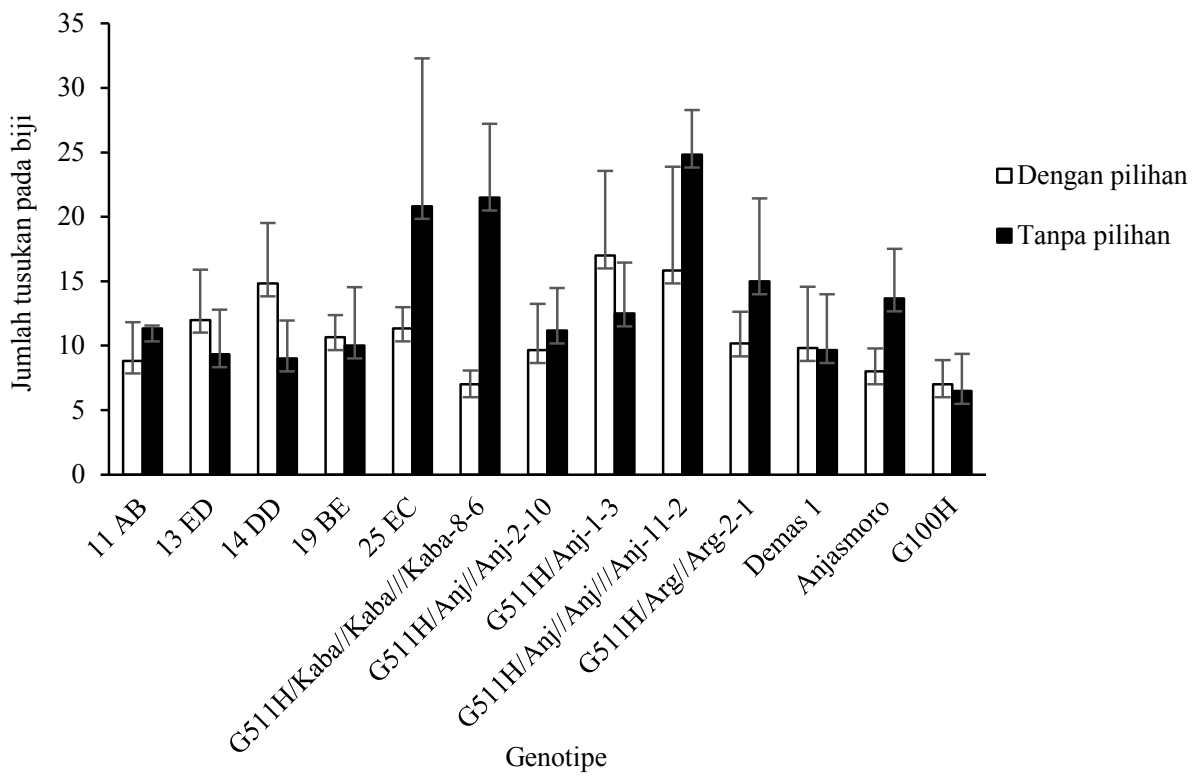

Gambar 1. Jumlah tusukan pada biji kedelai pada uji dengan dan tanpa pilihan 
Tabel 3. Ketahanan dari 13 genotipe kedelai pada uji dengan pilihan dan tanpa pilihan

\begin{tabular}{|c|c|c|c|c|c|c|c|c|c|}
\hline \multirow{3}{*}{ No } & \multirow{3}{*}{ Genotipe } & \multicolumn{4}{|c|}{ Uji dengan pilihan } & \multicolumn{4}{|c|}{ Uji tanpa pilihan } \\
\hline & & \multicolumn{4}{|c|}{ Intensitas kerusakan $(\%) \pm \mathrm{SD}$} & \multicolumn{4}{|c|}{ Intensitas kerusakan $(\%) \pm \mathrm{SD}$} \\
\hline & & Polong & Kriteria & Biji & Kriteria & Polong & Kriteria & Biji & Kriteria \\
\hline 1 & G1 & $17.99 \pm 8.35$ & $\mathrm{~T}$ & $17.57 \pm 5.28$ & $\mathrm{~T}$ & $47.52 \pm 12.51$ & $\mathrm{AR}$ & $35.91 \pm 7.71$ & AT \\
\hline 2 & $\mathrm{G} 2$ & $25.39 \pm 1.25$ & AT & $22.80 \pm 13.19$ & AT & $37.84 \pm 2.47$ & AT & $24.26 \pm 4.17$ & AT \\
\hline 3 & G3 & $44.22 \pm 18.98$ & AR & $33.55 \pm 16.16$ & AT & $35.84 \pm 17.67$ & AT & $16.75 \pm 4.20$ & $\mathrm{~T}$ \\
\hline 4 & G4 & $17.06 \pm 4.98$ & $\mathrm{~T}$ & $16.02 \pm 8.79$ & $\mathrm{~T}$ & $18.90 \pm 3.07$ & $\mathrm{~T}$ & $13.19 \pm 5.66$ & $\mathrm{~T}$ \\
\hline 5 & G5 & $27.80 \pm 13.05$ & AT & $21.34 \pm 13.49$ & AT & $30.97 \pm 15.08$ & AT & $52.48 \pm 27.69$ & $\mathrm{AR}$ \\
\hline 6 & G6 & $31.17 \pm 16.01$ & AT & $11.58 \pm 5.41$ & $\mathrm{~T}$ & $41.71 \pm 18.11$ & $\mathrm{AR}$ & $43.20 \pm 18.06$ & $\mathrm{AR}$ \\
\hline 7 & G7 & $24.39 \pm 14.83$ & AT & $10.94 \pm 4.07$ & $\mathrm{~T}$ & $38.53 \pm 11.33$ & AT & $22.24 \pm 13.06$ & AT \\
\hline 8 & G8 & $17.78 \pm 8.24$ & $\mathrm{~T}$ & $41.14 \pm 21.77$ & $\mathrm{AR}$ & $22.77 \pm 4.81$ & AT & $23.49 \pm 9.46$ & AT \\
\hline 9 & G9 & $11.03 \pm 2.75$ & $\mathrm{~T}$ & $27.52 \pm 15.24$ & AT & $41.54 \pm 17.36$ & AR & $72.38 \pm 11.77$ & $\mathrm{R}$ \\
\hline 10 & G10 & $24.72 \pm 11.31$ & AT & $23.74 \pm 8.76$ & AT & $41.66 \pm 15.83$ & AR & $27.24 \pm 5.73$ & $\mathrm{AT}$ \\
\hline 11 & G11 & $23.06 \pm 12.10$ & AT & $17.74 \pm 12.84$ & $\mathrm{~T}$ & $45.35 \pm 18.75$ & AR & $36.98 \pm 18.79$ & $\mathrm{AT}$ \\
\hline 12 & G12 & $29.91 \pm 6.77$ & AT & $16.97 \pm 3.07$ & $\mathrm{~T}$ & $46.41 \pm 9.55$ & AR & $43.83 \pm 7.72$ & AR \\
\hline 13 & G13 & $26.36 \pm 9.77$ & AT & $11.16 \pm 5.52$ & $\mathrm{~T}$ & $34.20 \pm 5.72$ & AT & $13.70 \pm 2.98$ & $\mathrm{~T}$ \\
\hline & Rata-rata & 24.68 & & 20.93 & & 37.17 & & 32.74 & \\
\hline
\end{tabular}

Keterangan: G1 = 11 AB; G2 = 13 ED; G3 = 14 DD; G4 = 19 BE; G5 = 25 EC; G6 = G511H/Kaba//Kaba///Kaba-8-6; G7 = G511H/Anjs// Anjs-2-10; G8 = G511H/Anjs-1-3; G9 = G511H/Anj//Anj///Anj-11-2; G10 = G511H/Arg//Arg-2-1; G11 = Demas 1; G12 = Anjasmoro; $\mathrm{G} 13=\mathrm{G} 100 \mathrm{H}$ (pembanding tahan); $\mathrm{T}=$ tahan; $\mathrm{AT}=$ agak tahan; $\mathrm{AR}=$ agak rentan; $\mathrm{R}=$ rentan; $\mathrm{SD}=\mathrm{standar}$ deviasi

Genotipe 25 EC (G5) dan G511H/Arg//Arg-2-1 (G10) memiliki jumlah polong terbanyak. Genotipe dengan jumlah biji per tanaman terbanyak adalah G511H/Anj//Anj///Anj11-2 (G9) yaitu sebanyak 46 biji per tanaman. Berat biji per tanaman tertinggi adalah genotipe 13 ED (G2) yakni 4.67 g per tanaman. Karakter agronomi pada uji tanpa pilihan memperlihatkan keragaan yang lebih tinggi dibandingkan dengan keragaan pada uji dengan pilihan. Hal ini disebabkan pada uji tanpa pilihan setiap genotipe disungkup oleh kain kasa secara mandiri sehingga penerimaan cahaya lebih sedikit dibandingkan dengan uji dengan pilihan.

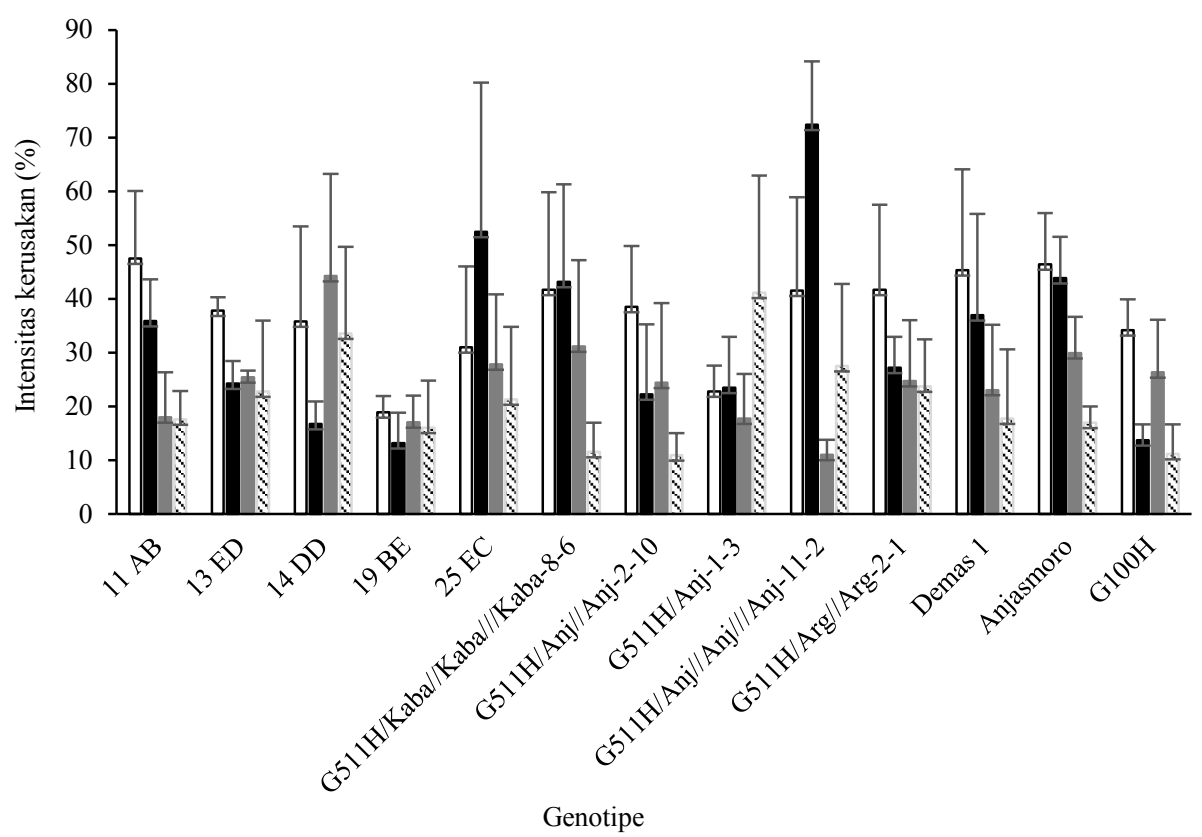

口ITPL - tanpa pilihan

ITBJ - tanpa pilihan ITPL - dengan pilihan $s$ ITBJ - tanpa pilihan

Gambar 2. Intensitas kerusakan polong (ITPL) dan biji (ITBJ) kedelai pada uji dengan dan tanpa pilihan 
Keterkaitan Karakter Agronomi dengan Intensitas Kerusakan

Penelusuran ketahanan kedelai terhadap hama kepik coklat dilakukan terhadap intensitas kerusakan biji melalui uji dengan dan tanpa pilihan. Pada uji dengan pilihan, intensitas kerusakan biji secara kuat ditentukan oleh jumlah tusukan pada biji $\left(\mathrm{r}=0.905^{* *}\right)$, sedangkan karakter jumlah biji dan berat biji/tanaman nilai korelasinya sepadan namun tidak berbeda nyata. Pola yang sama juga terjadi pada uji tanpa pilihan dimana intensitas kerusakan biji berkorelasi dengan jumlah tusukan $\left(\mathrm{r}=0.859^{*}\right)$ (Tabel 4). Hubungan antara jumlah biji dengan berat biji per tanaman nyata pada uji tanpa pilihan $\left(\mathrm{r}=0.958^{* *}\right)$. Pada penelitian ini tidak diperoleh hubungan yang nyata antara jumlah tusukan pada biji dengan jumlah biji per tanaman, baik pada uji dengan dan tanpa pilihan.

Penelusuran lebih jauh hubungan antara karakter agronomi dengan intensitas kerusakan biji dengan menggunakan sidik lintas disampaikan pada Tabel 5 untuk uji dengan pilihan dan Tabel 6 untuk uji tanpa pilihan. Diantara karakter tinggi tanaman, jumlah polong, jumlah biji, berat biji per tanaman dan jumlah tusukan pada biji, maka jumlah tusukan pada biji memiliki pengaruh langsung terkuat (1.158), diikuti oleh jumlah biji (-0.394). Karakter jumlah tusukan memiliki korelasi yang kuat dengan intensitas kerusakan biji dan juga memiliki pengaruh langsung yang kuat, menunjukkan bahwa jumlah tusukan pada biji menentukan intensitas kerusakan pada biji oleh hama kepik coklat. Peran dari jumlah tusukan pada biji hanya diperlemah oleh pengaruh tidak langsung melewati karakter jumlah biji per tanaman (-0.252). Hal serupa dapat terjadi pada pengaruh langsung dari karakter jumlah biji (-0.393) yang diperlemah oleh pengaruh tidak langsungnya melewati karakter jumlah tusukan pada biji. Hal ini memberikan isyarat bahwa semakin banyak jumlah biji per tanaman akan meningkatkan kemungkinan jumlah tusukan pada biji dan berpeluang akan meningkatkan kerugian hasil biji, terutama pada genotipe yang rentan.

Nilai korelasi pada uji tanpa pilihan, memperlihatkan pola yang sama yaitu jumlah tusukan berkorelasi positif nyata dengan intensitas kerusakan biji $\left(r=0.859^{*}\right)$, dan jumlah biji per tanaman berkorelasi positif nyata dengan berat biji per tanaman $\left(r=0.958^{* *}\right)$ (Tabel 4). Pola sidik lintas pada uji tanpa pilihan, terlihat pengaruh langsung karakter agronomi terhadap intensitas kerusakan biji tertinggi adalah karakter berat biji per tanaman (6.080) diikuti oleh karakter jumlah biji (-4.427) (Tabel 6). Berbeda dengan pola hubungan pada uji dengan pilihan, pada uji tanpa pilihan, pengaruh langsung berat biji per tanaman diperlemah oleh

Tabel 4. Korelasi karakter agronomi dengan intensitas serangan pada biji pada uji dengan pilihan

\begin{tabular}{lcccccc}
\hline Karakter & ITBJ & TTG & JPL & JBJ & B/T & TSBJ \\
\hline ITBJ & 1 & 0.324 & 0.116 & 0.352 & 0.399 & $0.905^{* *}$ \\
TTG & -0.539 & 1 & -0.252 & 0.259 & 0.292 & 0.431 \\
JPL & -0.222 & 0.439 & 1 & 0.300 & 0.260 & 0.146 \\
JBJ & -0.077 & 0.287 & 0.796 & 1 & 0.480 & 0.640 \\
B/T & -0.103 & 0.366 & 0.837 & $0.958^{* *}$ & 1 & 0.461 \\
TSBJ & $0.859 *$ & -0.476 & 0.046 & 0.343 & -0.284 & 1 \\
\hline
\end{tabular}

Keterangan: Atas diagonal = uji dengan pilihan; bawah diagonal = uji tanpa pilihan; TTG = tinggi $\operatorname{tanaman}(\mathrm{cm})$; JPL = jumlah polong per tanaman; JBJ = jumlah biji per tanaman; B/T = bobot biji per tanaman; TSBJ = jumlah tusukan pada biji; ITPL = intensitas kerusakan polong (\%); ITBJ = intensitas kerusakan biji (\%); * = berkorelasi nyata pada taraf 5\%; ** = berkorelasi sangat nyata pada taraf $1 \%$

Tabel 5. Pengaruh langsung dan tidak langsung dari karakter agronomi terhadap intensitas kerusakan biji pada uji dengan pilihan

\begin{tabular}{lcccccc}
\hline Karakter & TTG & JPL & JBJ & B/T & TSBJ & r \\
\hline TTG & $\mathbf{- 0 . 0 8 8}$ & -0.006 & -0.102 & 0.022 & 0.499 & 0.324 \\
JPL & 0.022 & $\mathbf{0 . 0 2 3}$ & -0.118 & 0.019 & 0.169 & 0.116 \\
JBJ & -0.023 & -0.007 & $\mathbf{- 0 . 3 9 4}$ & 0.036 & 0.741 & 0.352 \\
B/T & -0.026 & 0.006 & -0.189 & $\mathbf{0 . 0 7 4}$ & 0.534 & 0.399 \\
TSBJ & -0.038 & 0.003 & -0.252 & 0.034 & $\mathbf{1 . 1 5 8}$ & 0.905 \\
\hline
\end{tabular}

Keterangan: TTG = tinggi tanaman $(\mathrm{cm}) ; \mathrm{JPL}=$ jumlah polong/tanaman; JBJ = jumlah biji per tanaman; B/T = bobot biji per tanaman; TSBJ = jumlah tusukan pada biji; ITPL = intensitas kerusakan polong (\%); ITBJ = intensitas kerusakan biji (\%); data dengan huruf tebal $($ diagonal $)=$ pengaruh langsung; data dengan huruf tidak tebal (di atas dan di bawah diagonal) $=$ pengaruh tidak langsung; $r=$ koefisien korelasi 
Tabel 6. Pengaruh langsung dan tidak langsung dari karakter agronomi terhadap intensitas kerusakan biji pada uji tanpa pilihan

\begin{tabular}{lcccccc}
\hline Karakter & TTG & JPL & JBJ & B/T & TSBJ & r \\
\hline TTG & $\mathbf{- 0 . 3 5 6}$ & -0.864 & -1.271 & 2.225 & -0.272 & -0.539 \\
JPL & 0.156 & $\mathbf{- 1 . 9 6 9}$ & -3.524 & 5.089 & 0.026 & -0.222 \\
JBJ & -0.102 & -1.567 & $\mathbf{- 4 . 4 2 7}$ & 5.825 & 0.196 & -0.077 \\
B/T & -0.130 & -1.648 & -4.241 & $\mathbf{6 . 0 8 0}$ & -0.162 & -0.103 \\
TSBJ & 0.169 & -0.091 & -1.518 & 1.727 & $\mathbf{0 . 5 7 1}$ & 0.859 \\
\hline
\end{tabular}

Keterangan: TTG = tinggi tanaman $(\mathrm{cm})$; JPL = jumlah polong per tanaman; JBJ = jumlah biji per tanaman; B/T = Bobot biji per tanaman; TSBJ = Jumlah tusukan pada biji; ITPL = Intensitas kerusakan polong (\%); ITBJ = Intensitas kerusakan biji (\%); data dengan huruf tebal $($ diagonal $)=$ pengaruh langsung; data dengan huruf tidak tebal $($ di atas dan di bawah diagonal $)=$ pengaruh tidak langsung; $r=$ koefisien korelasi

pengaruh tidak langsungnya melewati karakter jumlah biji per tanaman (-4.241). Pola yang sama, pengaruh langsung karakter jumlah biji diperlemah secara kuat pada saat melewati karakter berat biji per tanaman (5.825). Pada uji tanpa pilihan tercermin bahwa semakin berat bobot biji per tanaman akan meningkatkan intensitas kerusakan biji. Perilaku karakter jumlah biji per tanaman adalah mirip dengan uji dengan pilihan, semakin banyak jumlah biji akan meningkatkan intensitas kerusakan biji oleh hama kepik coklat.

Krisnawati et al. (2016) menyampaikan bahwa jumlah polong, jumlah biji dan berat biji tidak berpengaruh terhadap intensitas kerusakan polong maupun biji akibat serangan hama kepik coklat namun antara intensitas kerusakan polong dan intensitas kerusakan pada biji memiliki korelasi yang nyata positif. Perbedaan faktor penentu ketahahan kedelai terhadap hama kepik coklat ditentukan oleh tingkat ketahanan dari genotipe kedelai yang diuji. Selain itu, terhadap ketahanan terhadap serangan hama juga ditentukan oleh faktor fisik tanaman yaitu trikoma atau bulu pada tanaman (Souza et al., 2012), dan faktor kimiawi berupa produksi metabolit primer (protein inhibitor dan enzim antioksidan) dan produksi metabolit sekunder (asam fenolik, flavonoid, dan isoflavon) (Michereff et al., 2011; Colazza dan Wajnberg 2013).

Teridentifikasinya genotipe kedelai yang relatif tahan terhadap hama kepik coklat memliki dua arti penting yaitu dapat dikembangkan sebagai varietas unggul atau digunakan sebagai sumber gen ketahanan. Pada penelitian ini genotipe 19 BE (G4) yang konsisten tahan terhadap hama kepik coklat berpeluang diuji lanjut pada uji adaptasi dan dilepas sebagai varietas unggul.

\section{KESIMPULAN}

Terdapat indikasi bahwa semakin banyak jumlah biji/ tanaman akan meningkatan kemungkinan jumlah tusukan pada biji oleh hama kepik coklat, sehingga meningkatkan intensitas kerusakan biji. Genotipe $11 \mathrm{AB}$ dan $19 \mathrm{BE}$ konsisten tahan berdasarkan intensitas kerusakan polong maupun biji pada uji dengan pilihan. Genotipe $19 \mathrm{BE}$ konsisten tahan terhadap serangan hama pengisap polong berdasarkan intensitas kerusakan polong maupun biji pada uji dengan dan tanpa pilihan.

\section{UCAPAN TERIMA KASIH}

Disampaikan terima kasih kepada Arifin, S.P. dan Antoni yang telah membantu pelaksanaan penelitian yang dibiayai oleh program KP4S Badan Litbang Pertanian tahun 2018 .

\section{DAFTAR PUSTAKA}

Arifin, M., W. Tengkano. 2008. Tingkat kerusakan ekonomi hama kepik coklat pada kedelai. Penelitian Pertanian 27:47-54.

Asadi, A., Purwantoro, S. Yakub. 2012. Genetic control of soybean resistance to soybean pod sucker (Riptortus linearis L.). Agrivita 34:28-35.

Bae, S.D., H.J. Kim, B.P. Mainali. 2014. Infestation of Riptortus pedestris (Fabricius) decreases the nutritional quality and germination potential of soybean seeds. J. Asia-Pacific Entomol. 17:477-481.

Bayu, M.S.I.Y., A. Krisnawati, M.M. Adie. 2017. Respon genotipe kedelai biji besar dan umur genjah terhadap kompleks hama pengisap polong. J. Hama Penyakit Tumb. Tropika 17:128-136.

Bayu, M.S.Y.I., W. Tengkano. 2014. Evaluasi ketahanan galur-galur harapan kedelai toleran lahan masam dan kekeringan terhadap kepik coklat. hal. 322-327. Dalam D. Armita, A.W. Sektiono (Eds.). Prosiding Seminar Nasional 3 in 1, Hortikultura, Agronomi, dan Pemuliaan Tanaman. Malang 21 Agustus 2013.

Colazza, S., W. Wajnberg. 2013. Chemical ecology of insect parasitoids: towards a new era. p. 1-8. In E. Wajnberg, S. Colazza (Eds.). Chemical Ecology of Insect Parasitoids. 1st Edition. John Wiley \& Sons Ltd., Chichester, UK. 
Da Graca, J.P., E.U. Tatiana, J. Tatiani, S.V. Simone, C.S. Mariana, C.N.O. Maria, M.Z. Sonia, J.P. Stephen, A.P. John, A.B. Michael, B.H. Clara. 2016. The natural plant stress elicitor cis-jasmone causes cultivar-dependent reduction in growth of the stink bug, Euschistus heros and associated changes in flavonoid concentrations in soybean, Glycine max. Phytochemistry 131:84-91.

De Godoi, C.R.C., J.B. Pinheiro. 2009. Genetic parameters and selection strategies for soybean genotypes resistant to the stink bug-complex. Genet. Mol. Biol. 32:328-336.

Depieri, R.A., A.R. Panizzi. 2011. Duration of feeding and superficial and in-depth damage to soybean seed by selected species of stink bugs (Heteroptera: Pentatomidae). Neotrop. Entomol. 40:197-203.

Kim, S., U.T. Lim. 2010. Seasonal occurrence pattern and within-plant egg distribution of bean bug, Riptortus pedestris (Fabricius) (Hemiptera: Alydidae), and its egg parasitoids in soybean fields. Appl. Entomol. Zool. 45:457-464.

Krisnawati, A., M.M. Adie. 2018. Evaluation of soybean resistance to pod-sucking bug, Riptortus linearis and performance of its agronomic characters. Biosaintifika 10:213-222.

Krisnawati, A., M.S.Y.I. Bayu, M.M. Adie. 2016. Identification of soybean resistance to pod sucking bug (Riptortus linearis F.) by no-choice test. Biosaintifika 8:406-413.

Krisnawati, A., M.S.Y.I. Bayu, M.M. Adie. 2017. Screening of soybean genotypes for resistance to pod sucking bug, Riptortus linearis. Nusantara Biosci. 2:181187.

Nurkartika, R., S. Ilyas, M. Machmud. 2017. Aplikasi agens hayati untuk mengendalikan hawar daun bakteri pada produksi beih padi. J. Agron. Indonesia 45:235-242.

Mainali, B.P., U.T. Lim. 2012. Annual pattern of occurrence of Riptortus pedestris (Hemiptera: Alydidae) and its egg parasitoids Ooencyrtus nezarae Ishii and Gryon japonicum (Ashmead) in Andong, Korea. Crop. Prot. $36: 37-42$.
Michereff, M.F.F., R.A. Laumann, M. Borges, M. MichereffFilho, I.R. Diniz, A.L.F. Neto, M.C.B. Moreas. 2011. Volatiles mediating a plant-herbivore-natural enemy interaction in resistant and susceptible soybean cultivars. J. Chem. Ecol. 37:273-285.

Musser, F.R., A.L. Catchot, B.K. Gibson, K.S. Knighten. 2011. Economic injury levels for southern green stink bugs (Hemiptera: Pentatomidae) in R7 growth stage soybeans. Crop Prot. 30:63-69.

Owens, D.R., D.A. Herbert, G.P. Dively, D.D. Reisig, T.P. Kuhar. 2013. Does feeding by Halyomorpha halys (Hemiptera: Pentatomidae) reduce soybean seed quality and yield?. J. Econ. Entomol. 106:13171323.

Rahman, M.M., U.T. Lim. 2017. Evaluation of mature soybean pods as a food source for two pod-sucking bugs, Riptortus pedestris (Hemiptera: Alydidae) and Halyomorpha halys (Hemiptera:Pentatomidae). PLoS ONE 12(4):e0176187. https://doi.org/10.1371/ journal.pone. 0176187 .

Siburian, D., Y. Pangestuningsih, L. Lubis. 2013. Pengaruh jenis insektisida terhadap hama polong Riptortus linearis (Hemiptera: Coreidae) dan Etiella zinckinella Treit. (Lepidoptera: Pyralidae) pada tanaman kedelai (Glycine max L.). J. Agroekotek. 2:893-904.

Singh, K.B., B.D. Chaudhary. 1977. Biometrical Methods in Quantitative Genetic Analysis. Kalyani Press. New Delhi, IN.

Souza, B.H.S., A.L.B. Junior, J.C. Janini, A.G.D. Silva, N.E.L. Rodrigues. 2012. Feeding of Spodoptera eridania (Lepidoptera: Noctuidae) on soybean genotypes. Rev. Colombiana Entomol. 38:215-223.

Suharsono, L. Sulistyowati. 2012. Expression of resistance of soybean to the pod sucking bug Riptortus linearis (Hemiptera: Coreidae). Agrivita 34:55-59.

Tillman, P.G. 2013. Stink bugs (Heteroptera: Pentatomidae) and their natural enemies in alfalfa in South Georgia. J. Entomol. Sci. 48:1-8. 